\title{
ГЛАВА 8
}

\section{ХЛОРОРГАНИЧЕСКИЕ ПЕСТИЦИДЫ (ХОП) В МОРСКИХ ПТИЦАХ И МЛЕКОПИТАЮЩИХ ОХОТСКОГО И БЕРИНГОВА МОРЕЙ}

\author{
В.Ю. Цыганков ${ }^{1,2}$, М.Д. Боярова ${ }^{1}$, М.М. Донещ, \\ Н.К. Христофорова ${ }^{2}$
}

В главе приведены результаты определения изомеров ГХЦГ, ДДТ и его метаболитов в органах морских птиц (Larus schistisagus, Aethia cristatella, Aethia pusilla, Fulmarus glacialis, Oceanodroma furcata) и морских млекопитающих (Eschrichtius robustus, Odobenus rosmarus divergens) из Охотского и Берингова морей. Показано, что видовые особенности аккумуля-

${ }^{1}$ Школа биомедицины, Дальневосточный федеральный университет (ДВФУ), 690922, Владивосток, о. Русский, п. Аякс, 10. E-mail: tsig_90@mail.ru.

${ }^{2}$ Школа естественных наук, Дальневосточный федеральный университет (ДВФУ), 690922, Владивосток, о. Русский, п. Аякс, 10.

${ }^{1}$ School of Biomedicine, Far Eastern Federal University, 10 Ajax Bay, Russky Island Vladivostok, Russia,690922.E-mail: tsig_90@mail.ru.

${ }^{2}$ School of School of Natural Sciences, Far Eastern Federal University, 10 Ajax Bay, Russky Island Vladivostok, Russia, 690922.

Для ичитирования: Цыганков В.Ю., Боярова М.Д., Донец М.М., Христофорова Н.К. Хлорорганические пестициды (ХОП) в морских птицах и млекопитающих Охотского и Берингова морей // Стойкие органические загрязняющие вещества (CO3) в Дальневосточном регионе: моря, организмы, человек : монография / В.Ю. Цыганков, М.М. Донец, Н.К. Христофорова [и др.] ; науч. ред. В.Ю. Цыганков. - Владивосток : Изд-во Дальневост. федерал. ун-та, 2020. - С. 211-233. https://doi.org/10.24866/7444-4891-2/211-233.

For citing: Tsygankov V.Yu., Boyarova M.D., Donets M.M., Khristoforova N.K. Organochlorine pesticides (OCPs) in seabirds and marine mammals of the Sea of Okhotsk and the Bering sea // Persistent organic pollutants (POPs) in the Far Eastern Region: Seas, Organisms, Human: monograph / V.Yu. Tsygankov, M.M. Donets, N.K. Khristoforova [et al.] ; ed. by V.Yu. Tsygankov. - Vladivostok : Publishing House of the Far Eastern Federal University, 2020. - P. 211-233. - https://doi.org/10.24866/7444-4891-2/211-233. 
ции липофильных ксенобиотиков в значительной степени обусловлены характером пищи и общим содержанием жира в органах.

Ключевые слова: ГХЦГ; ДДТ; морские птицы; морские млекопитающие; Охотское море; Берингово море.

\title{
CHAPTER 8. ORGANOCHLORINE PESTICIDES (OCPS) IN SEABIRDS AND MARINE MAMMALS FROM THE SEA OF OKHOTSK AND THE BERING SEA
}

\author{
V.Yu. Tsygankov ${ }^{1,2}$, M.D. Boyarova ${ }^{1}$, M.M. Donets ${ }^{1}$, \\ N.K. Khristoforova ${ }^{1,3}$
}

In this chapter, research results of $\mathrm{HCH}$ isomers, DDT and its metabolites in the organs of seabirds (Larus schistisagus, Aethia cristatella, Aethia pusilla, Fulmarus glacialis, Oceanodroma furcata) and marine mammals (Eschrichtius robustus, Odobenus rosmarus divergens), which collected in the Sea of Okhotsk and the Bering Sea, are presented. The specific features in the accumulation of lipophilic xenobiotics are associated with the nutritional factor and the total fat content in individual organs.

Keywords: HCHs; DDTs; seabirds; marine mammals; the Sea of Okhotsk; the Bering Sea.

На рубеже 1960-70 гг. в разных регионах мира наблюдалась массовая гибель популяций диких птиц. Одной из ее причин оказалось применение стойких органических загрязняющих веществ (СО3), в частности, хлорорганических пестицидов (ХОП). Их широко использовали в качестве инсектицидов для борьбы с переносчиками малярии, в сельском и коммунальном хозяйстве. Эти антропогенные вещества, являясь липофильными соединениями, способны накапливаться в объектах окружающей среды и оказывать негативное влияние на живые организмы. В результате отравле- 
ния эндрином погибли куропатки и фазаны; дильдрином - белоголовые орланы и гуси; ДДТ (дихлордифенилтрихлорэтан) - бакланы, пеликаны и чайки; линданом (ГХЦГ - гексахлорциклогексан) - скворцы $[3,10]$.

После запрета использования и производства ряда пестицидов гибель птиц значительно снизилась, но случаи отравления продолжались. Оказалось, что на территориях, загрязненных ХОП, птицы особенно чувствительны к другим группам химических и биологических повреждающих агентов. Так, присутствие ДДЕ (дихлордифенилдихлорэтилен) маскирует эффект отрицательного воздействия ртути на размножение птиц [3, 6].

Летальные дозы пестицидов видоспецифичны и находятся в диапазоне от 4 (для желтушника и японского перепела) до 65 мг/кг (для воробьев). В ряде экспериментов были выявлены критические концентрации ХОП в мозге птиц [23].

В Великобритании впервые была отмечена корреляция между истончением яичной скорлупы и ухудшением воспроизводства в популяциях сокола-сапсана и ястреба-перепелятника в местах использования стойких хлорорганических инсектицидов. Толщина скорлупы уменьшилась к концу 1960-х гг., по сравнению с 1940 г., у 9 из 17 исследованных особей на 5-19\% [15]. Исследования в США и Канаде также выявили степень истончения скорлупы яиц: толщина и вес скорлупы у многих видов птиц уменьшились на 20\% [22, 23].

Птицы широко используются как биоиндикаторы для мониторинга загрязнения окружающей среды хлорорганическими поллютантами. Птицы могут быть как промежуточным, так и завершающим звеном трофической цепи. Питаясь живыми организмами, за счет биомагнификации они накапливают в своих органах более высокие концентрации токсичных веществ [25]. В зависимости от типа питания (фитофаги, планктонофаги, рыбоядные и др.) и характера миграций (перелетные и локальные) в органах и тканях птиц меняется и содержание СО3. В отсутствие локальных источников загрязнения, аккумуляция СО3 свидетельствует о глобальном загрязнении в результате трансграничного атмосферного переноса и транспорта поллютантов морскими течениями $[12,15]$.

Среди исследователей, занимающихся проблемами глобального загрязнения природной среды и влиянием этого процесса на животный мир, давно утвердилось мнение об Арктике как регионе-мишени. Своих источников антропогенного загрязнения Арктика практически не имеет, но она 
подвержена постоянному воздействию мощных переносов из более южных широт. Различные поллютанты воздушным или водным путем, а также за счет миграции организмов (так называемый «биотранспорт») легко достигают арктического региона, быстро включаясь в обмен веществом и энергией, оказывают негативное воздействие на экосистемы и их обитателей, в том числе млекопитающих [2, 5, 18, 22, 28, 29, 30].

Морских млекопитающих можно считать удобными видами для долгосрочного мониторинга загрязнения морской среды СОЗ. Они могут использоваться как индикаторы глобального загрязнения, так и биомониторы временных трендов в изменении загрязнения биосферы [26, 27].

\section{1. Морские птицы}

Нами исследован 41 образец органов пяти видов морских птиц - тихоокеанской чайки (Larus schistisagus), большой конюги (Aethia cristatella), конюги-крошки (Aethia pusilla), глупыша (Fulmarus glacialis) (белой и темной морфы), серой качурки (Oceanodroma furcata), собранных в июне и октябре 2012 г. в Охотском море с побережья Западной Камчатки и Курильских островов. В зависимости от размера птиц исследованы разные органы: перо, перо с кожей, мышцы, печень, тушки целиком (внутренние органы с перьями).

Пестициды обнаружены во всех образцах. Общее содержание в различных органах варьировало от 28 до 16095 нг/г липидов. В перьях диапазон значений составил 28-8289 нг/Г, в перьях с кожей - 1567-16095 нг/Г, в печени - 1679-2478 нг/г, в мышцах - 2230-3000 нг/г, в гомогенате органов - 12,5-15112 нг/г. Средние суммарные концентрации пестицидов в отдельных органах приведены на рисунке 8.1.

ДДТ обнаружен только в перьях глупышей, пойманных в июне, в пределах 975-1978 нг/г. ДДЕ присутствовал во всех образцах от 27 до 15276 нг/г. ДДД в пробах не был обнаружен вовсе.

$\gamma$-ГХЦГ обнаружен только в некоторых пробах: в перьях и перьях с кожей июньских глупышей - 177-467нг/г; в печени тихоокеанской чайки

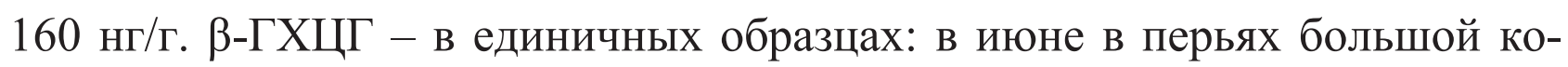


нюги, тушке крошечной конюги; в октябре в печени глупыша. Концентрация $\beta$-ГХЦГ составляла 555-1151 нг/г. $\alpha$-ГХЦГ найден практически во всех образцах в диапазоне от 160 до 3024 нг/г, за исключением глупыша, пойманного в октябре (отсутствует у одной особи в перьях, у другой присутствует только в мышцах) и тихоокеанской чайки (ниже пределов обнаружения в перьях одной особи). Среднее значение суммарной концентрации ХОП в июне (6580 нг/г) почти в 2 раза выше, чем в октябре (3442 нг/г).
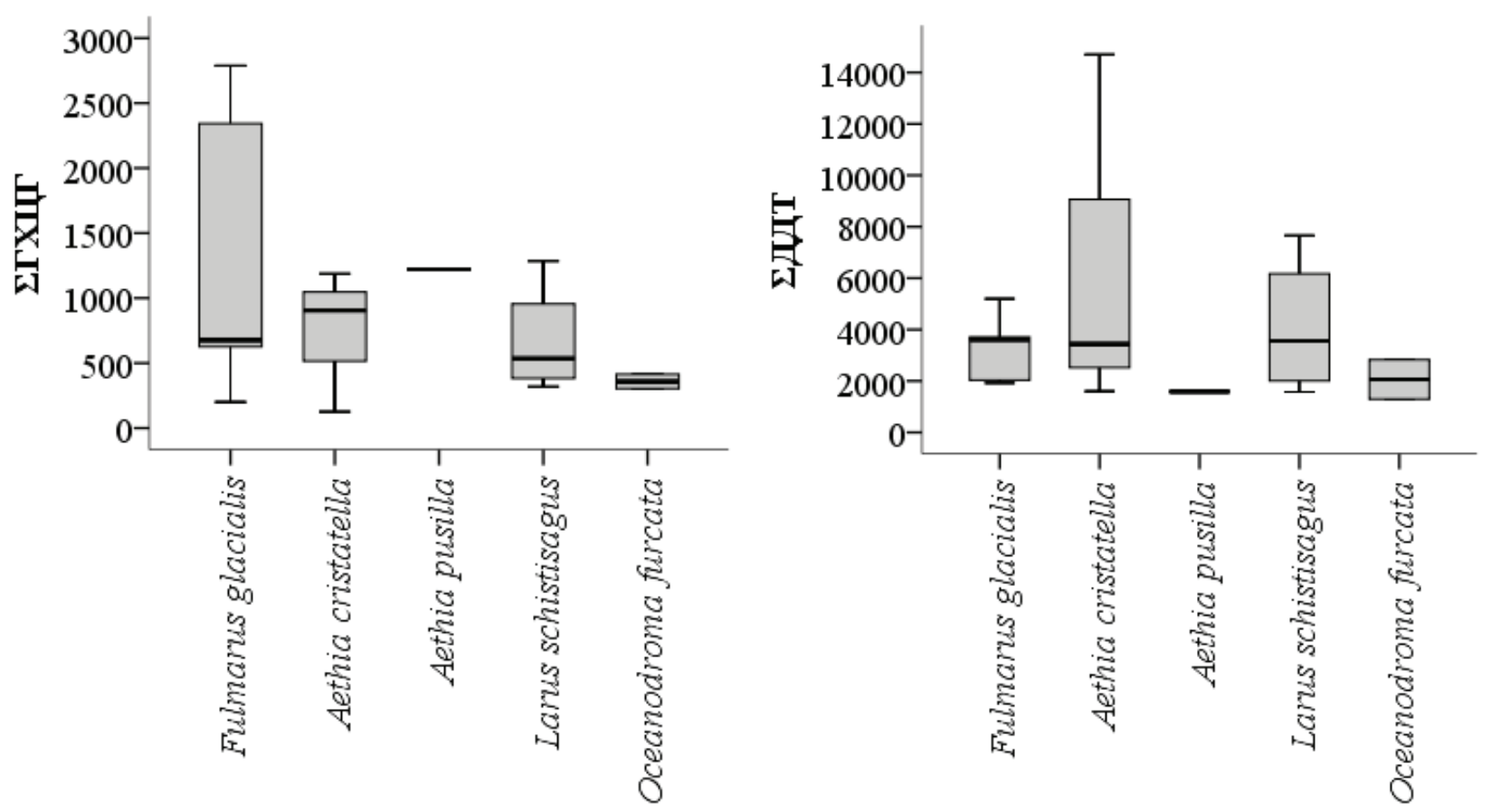

Puc. 8.1. Средняя концентрация (медиана) изомеров ГХЦГ, ДДТ и его метаболитов в органах и тканях птиц, нг/Г липидов

Tихоокеанская чайка Larus schistisagus. Суммарное содержание ХОП во всех органах тихоокеанской чайки находилось в пределах 156710357 нг/Г липидов. Концентрации $\alpha$-ГХЦГ варьировали от 200 до 2017 нг/г, количество $\beta$-ГХЦГ было ниже пределов обнаружения, $\gamma$-ГХЦГ найден в печени у одной из двух особей, где концентрация составила 160 нг/г, коэффициент $\alpha / \gamma-Г Х Ц Г ~-2,7$, что говорит о длительной циркуляции изомеров ГХЦГ в морской среде. Концентрации ДДТ и ДДД были ниже пределов обнаружения, содержание ДДЕ находилось в пределах от 1016 до 8339 нг/г.

Глуnыш Fulmarus glacialis. Диапазон суммарных концентраций ХОП - от 28 до 8135 нг/г липидов. Сумма изомеров ГХЦГ - от 200 до 
3040нг/г: $\alpha$-ГХЦГ - от 200 до 3024 нг/г; $\beta$-ГХЦГ обнаружен в одной из пяти птиц в печени, концентрация составила 555 нг/г; $\gamma$-ГХЦГ обнаружен в трех из пяти особей в перьях и перьях с кожей в пределах от 177 до 467 нг/г. Во всех пробах, где был обнаружен $\gamma$-ГХЦГ, коэффициент $\alpha / \gamma-$ ГХЦГ был выше 1.

Диапазон значений суммы ДДТ и его метаболитов варьировал от 28 до 5625 нг/г липидов: ДДТ найден у трех особей в перьях, диапазон 1440-1978 нг/Г липидов; ДДД - ниже предела обнаружения; ДДЕ варьировал от 28 до 5608 нг/г липидов. Отношение средних концентраций ДДТ и ДДЕ меньше 1, что показывает на «свежее» поступление ДДТ в морскую среду и организм птиц.

Больщая конюга Aethia cristatella. Минимальная суммарная концентрация ХОП составила 1842, максимальная - 16095 нг/г липидов. Диапазон суммарных значений ГХЦГ лежал в пределах 160-2214 нг/Г, $\alpha$-изомера - от 160 до 1062 нг/г. $\beta$-ГХЦГ обнаружен в одной из двух особей в перьях, концентрация составила 115 нг/г, $\gamma$-ГХЦГ - ниже предела обнаружения. ДДТ и ДДД - также ниже пределов обнаружения, диапазон ДДЕ - от 1604 до15276 нг/г.

Конюга-крошка Aethia pusilla. Сумма ХОП лежала в пределах от 2247 до 3499 нг/г. Суммарная концентрация изомеров ГХЦГ варьировала

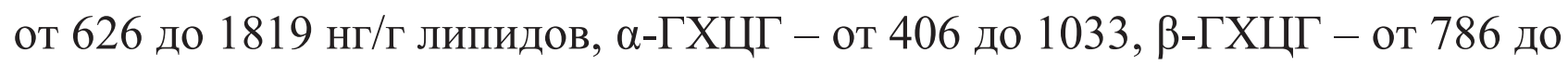
810 нг/г, $\gamma$-ГХЦГ не обнаружен. ДДТ и ДДД - ниже пределов обнаружения, ДДЕ варьирует от 1450 до 1679 нг/г.

Серая качурка Oceanodroma furcata. Исследована одна особь. Диапазон концентраций суммы ХОП - от 1705 до 3128 нг/г. Из изомеров ГХЦГ обнаружен только $\alpha$-изомер - от 303 до 415 нг/г. ДДТ и ДДД - ниже пределов обнаружения, ДДЕ варьирует от 1290 до 2825 нг/г.

Общее содержание пестицидов в тушке (органы и ткани) птиц. Максимальное значение ХОП отмечено у глупышей (5816 нг/г), минимальное - у серой качурки (1705 нг/г). Для ДДТ и его метаболитов выявлена схожая закономерность - максимальные уровни у глупышей (5608 нг/г), минимальные - у серой качурки (1209 нг/г). Наибольшее содержание изомеров ГХЦГ обнаружено у крошечной конюги (1819 нг/Г), наименьшее - у глупыша (208 нг/Г липидов). Средние концентрации ГХЦГ и ДДТ в отдельных органах представлены на рисунке 8.2. 

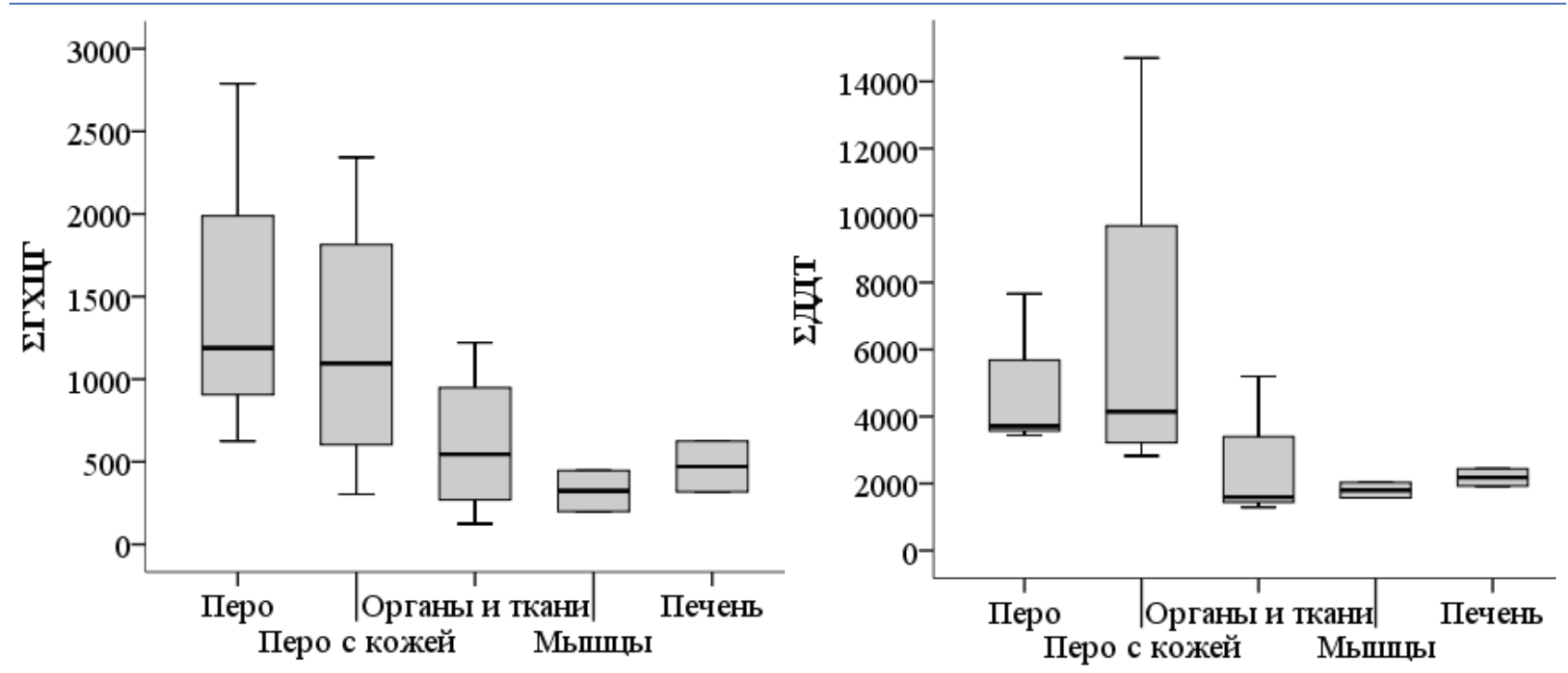

Puс. 8.2. Среднее содержание (медиана) изомеров ГХЦГ, ДДТ и его метаболитов в органах морских птиц, нг/г липидов

Содержание пестицидов в перьях. Самая высокая суммарная концентрация ХОП выявлена в перьях у тихоокеанской чайки (8289 нг/г липидов). У трех глупышей, добытых в июне, концентрации были высокие и близкие $(7119,7916$ и 8135 нг/г липидов), но в октябре концентрация ХОП у них резко снижалась (всего 28 нг/г). Наиболее высокая суммарная концентрация Д ДЕ (единственного выявленного метаболита ДДТ) обнаружена также у тихоокеанской чайки (766 нг/г), наименьшая - у глупыша, добытого в октябре (28 нг/г). Сумма изомеров ГХЦГ достигает максимальной величины у глупышей, добытых в июне (3040 нг/г), минимальной - у большой конюги $(160$ нг/г).

Содержание пестицидов в перьях с кожей. Максимальное суммарное количество ХОП и метаболитов ДДТ обнаружено у большой конюги (16095 и 15276 нг/г, соответственно), минимальное - у тихоокеанской чайки (1567 и 1016 нг/г соответственно). Наибольшее суммарное содержание изомеров ГХЦГ выявлено у глупыша (3047 нг/г), минимальное - у серой качурки (303 нг/г липидов).

ХОП в печени и мышцах определены у двух видов птиц, собранных в октябре: глупыш и тихоокеанская чайка.

Содержание пестицидов в печени. В печени глупыша суммарные количества ХОП (2478 нг/г) и метаболитов ДДТ (1923 нг/г) превышали таковые у чайки (1679 и 1376 нг/г соответственно). Максимальное содержание изомеров ГХЦГ обнаружено в печени тихоокеанской чайки (590 нг/г). 
Содержание пестицидов в мышцах. В мышцах тихоокеанской чайки суммарные количества ХОП (3000 нг/г) и метаболитов ДДТ (2775 нг/г) были выше, чем у глупыша (2230 и 2030 нг/г, соответственно). Сумма изомеров ГХЦГ (410 нг/г) была также выше, чем у глупыша (200 нг/г).

Исследованные виды птиц различаются размерами, образом жизни, и количеством подкожного жира. Известно, что ХОП концентрируются преимущественно в подкожном жире, поэтому у более крупных птиц содержание ХОП больше. Тихоокеанская чайка (средняя длина тела - 64 см) и глупыш (47 см) в перьях с кожей имеют сходные концентрации ХОП (5962 и 5949 нг/г, соответственно). В качурке (22 см), которая значительно меньше этих видов птиц, содержание пестицидов составило 3128 нг/г. Однако накопление и распределение пестицидов в органах птиц может регулироваться и другими дополнительными факторами. Например, у большой конюги размером 26 см, содержание ХОП в перьях с кожей достигало 15604 нг/г. Выяснение причины таких высоких концентраций ХОП у этого вида требует дальнейших исследований.

На содержании пестицидов во внутренних органах птиц отражается и спектр питания. К кормовым объектам глупыша относятся организмы, имеющие высокий коэффициент накопления ХОП (рыбы, икра рыб, моллюски, ракообразные и другие беспозвоночные, падаль, внутренности китов, различные жирные отбросы и т.д.), следствием чего является высокое содержание пестицидов в тушке птиц (5874 нг/г). Большая конюга, конюга-крошка и качурка питаются мелкими ракообразными, морскими беспозвоночными, амфиподами и др., которые аккумулируют пестициды в меньшей степени, чем кормовые объекты глупыша. Отражением этого является и меньшее содержание ХОП во внутренних органах этих видов: 1730, 2804 и 1705 нг/г липидов, соответственно.

Данные об уровнях содержания ГХЦГ и ДДТ в птицах из Охотского моря и других районов Мирового океана представлены в таблице 8.1.

Общее содержание ХОП в тихоокеанской чайке, серой качурке, крошечной конюге из Охотского моря выше, чем в люрике (Alle alle), толстоклювой кайре (Uria lomvia), обыкновенной моевке (Rissa tridactyla) и обыкновенном чистике (Cepphus grylle) из моря Баффина, и ниже, чем в глупыше (Fulmarus glacialis) из моря Баффина, клуше (Larus fuscus) и морской чайке (Larus marinus) из Исландии, бургомистре (Larus hyperboreus) из моря Баффина, белой чайке (Pagophila eburnea) и большом 
поморнике (Stercorarius skua) из Исландии и бургомистре (Larus hyperboreus) из Баренцева моря.

Таблища 8.1

\section{Суммарное содержание хлорорганических пестицидов (ДДТ и ГХЦГ) в морских птицах из различных районов мирового океана, нг/г липидов}

\begin{tabular}{lllll}
\hline Вид & Район & $\sum$ ДДТ & $\sum$ ГХЦГ & Источник \\
\hline Люрик (Alle alle) & Северный & 571,4 & 233,9 & {$[6]$} \\
Толстоклювая кайра (Uria lomvia) & Ледовитый & 1096,7 & 84,3 & \\
Обыкновенный чистик (Cepphus grylle) & океан, море & 1003,3 & 268,3 & \\
Обыкновенная моевка (Rissa tridactyla) & Баффина & 1277,1 & 45,3 & \\
Белая чайка (Pagophila eburnea) & & 7049,3 & 138,1 & \\
Бургомистр (Larus hyperboreus) & & 5956,1 & 449,2 & \\
Глупыш (Fulmarus glacialis) & & 4870,7 & 62,9 & \\
Морская чайка (Larus marinus) & Исландия & 3420 & 0 & [10] \\
Клуша (Larus fuscus) & & 3370 & 36,7 & \\
Большой поморник(Stercorrius skua) & & 54200 & 1400 & \\
Бургомистр (Larus hyperboreus) & Баренцево & 215109 & 1038 & [12] \\
& море & & & \\
Глупыш (Fulmarus glacialis) & Охотское & 3335,3 & 1630,47 & Настоящая \\
Большая конюга (Aethia cristatella) & море & 7575,36 & 884,78 & работа \\
Тихоокеанская чайка & & 3576,41 & 674,66 & \\
(Larus schistisagus) & & & & \\
Серая качурка (Oceanodroma furcata) & & 2017,05 & 377,1 & \\
Конюга-крошка (Aethia pusilla) & & 1583,5 & 1220,97 & \\
\hline
\end{tabular}

В органах и тканях большой конюги общий уровень ХОП ниже, чем у большого поморника из Исландии и бургомистра из Баренцева моря. У глупыша из Охотского моря сумма ХОП выше, чем у глупыша из моря Баффина, но ниже, чем у других птиц из моря Баффина.

Суммарное содержание метаболитов ДДТ у глупыша, тихоокеанской чайки, серой качурки, крошечной конюги, из Охотского моря выше, чем у люрика, толстоклювой кайры, обыкновенной моевки, обыкновенного чистика из моря Баффина, и ниже, чем у глупыша из моря Баффина, клуши из Исландии, морской чайки из Исландии, бургомистра из моря Баффина, белой чайки из Исландии, большого поморника из Исландии, бургомистра из Баренцева Моря. У всех исследованных птиц сумма метаболитов ДДТ ниже, чем у большого поморника из Исландии и бургомистра из Баренцева Моря. 
Концентрация сумм изомеров ГХЦГ у серой качурки выше, чем у обыкновенной моевки, глупыша, клуши, толстоклювой кайры, белой чайки, люрика, обыкновенного чистика и ниже остальных видов. У тихоокеанской чайки и большой конюги из Охотского моря сумма изомеров ГХЦГ выше, чем у обыкновенной моевки, глупыша, клуши, толстоклювой кайры, люрика, белой чайки, обыкновенного чистика, бургомистра из моря Баффина, и ниже, чем у остальных видов. У крошечной конюги из Охотского моря сумма изомеров ГХЦГ выше, чем у поморника из Исландии и ниже остальных видов. У глупыша из Охотского моря сумма изомеров ГХЦГ выше, чем у всех видов.

Во всех исследованных образцах и в данных, приведенных различными авторами (табл. 8.1) прослеживается общая закономерность - сумма изомеров ГХЦГ ниже сумм метаболитов ДДТ.

Все исследованные птицы являются, в основном, оседлыми видами, соответственно, уровень биоаккумуляции хлорорганических соединений птицами Охотского моря отражает уровень загрязнения данного региона. Приведенные в табл. 8.1 виды собраны в сходных широтах Северного полушария. Диапазон концентраций у всех птиц практически сходен, что указывает на близкую загрязненность морской среды в этих широтах.

Видовые особенности в аккумуляции ХОП в первую очередь могут быть связаны с типом питания. Например, бургомистр из Баренцева моря, питающийся рыбой, падалью, мелкими млекопитающими и яйцами других птиц, содержит в своем теле 216157 нг ХОП/Г липидов [12]. Яйца птиц богаты жиром, необходимым для развития эмбриона, соответственно, содержат высокие концентрации ХОП, так как в процессе овогенеза все токсичные вещества вместе с жиром из самки попадают в яйцо, которое может стать пищей других птиц $[16,19]$. Яйца и отдельно скорлупа птиц часто используются как индикаторы загрязнения ХОП, вследствие максимальной аккумуляции пестицидов по сравнению с другими морскими организмами [23].

Большой поморник, пища которого состоит главным образом из рыбы, которую он отнимает у других птиц, накапливает поллютантов до 55600 нг/г [10]. Рыбы, как правило, содержат в своем теле меньше пестицидов, в отличие от птиц и млекопитающих, так как являются невысоким звеном пищевой цепи, соответственно, содержание ХОП в поморнике значительно ниже, чем в бургомистре [44]. 
Обитатели моря Баффина (Северный Ледовитый океан) накапливают меньшее количество ХОП, за счет своей удаленности от потенциальных источников загрязнения. Например, глупыш, который питается ракообразными, рыбой, кальмарами, планктоном, при случае - падалью, содержит токсикантов 4933,5 нг/г [6].

Аккумуляция пестицидов у птиц влияет на различные стороны их физиологии, например, вызывает серьезное ухудшение репродуктивной функции и истончение скорлупы яиц, что приводит к нарушению эмбрионального развития и потере потомства [23]. Разный уровень аккумуляции ХОП у отдельных видов отражает различную степень загрязнения районов обитания. Видовые особенности в аккумуляции липофильных ксенобиотиков в немалой степени обусловлены как спектром питания, так и общим содержанием жира в отдельных органах. Обнаружение заметных концентраций ХОП в морских птицах Охотского моря, изолированного от активной сельскохозяйственной деятельности, служит свидетельством общего глобального фона СО3, сформировавшегося на планете в настоящее время.

\section{2. Морские млекопитающие}

Исследованы образцы органов (мышцы и печень) семи особей серого кита, добытых в сентябре 2010 г., и восьми особей тихоокеанского моржа, добытых в сентябре 2011 г. в прибрежных водах п. Лорино (Мечигменский залив, Чукотский автономный округ, Берингово море) местными охотниками-китобоями.

Международная китобойная комиссия (International Whaling Commission - IWC) предоставила исключительное право добывать серого кита чукотско-калифорнийской популяции коренным жителям Чукотки (Россия) и Аляски (США) для удовлетворения традиционных потребностей и поддержания традиционного уклада жизни. 


\subsection{1. Серый кит (Eschrichtius robustus)}

Пестициды обнаружены во всех пробах. Диапазон концентраций ХОП в органах кита был широким. Концентрации в печени значительно выше, чем в мышцах (рис. 8.3). Вероятно, это связано с детоксицирующими свойствами печени, в которой происходит основная деградация токсикантов в организме.
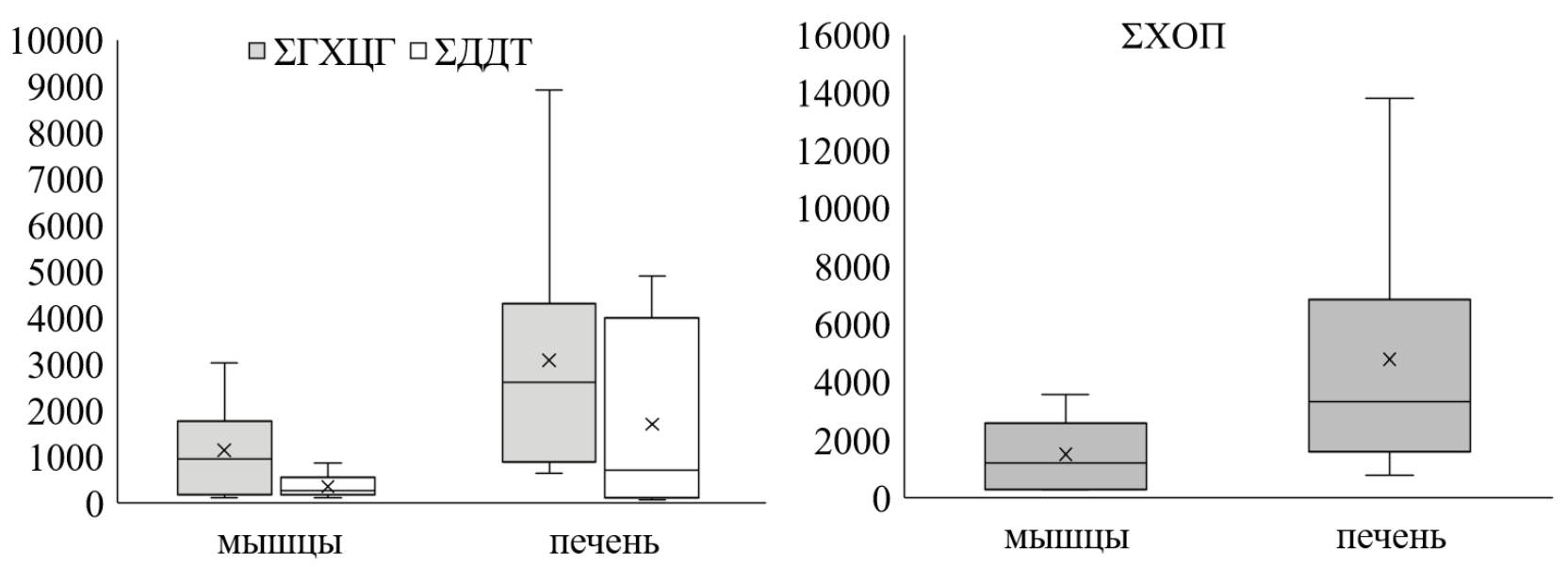

Puc. 8.3. Суммарное содержание ГХЦГ, ДДТ и ХОП в мышцах и печени серого кита, нг/Г липидов

В целом, мы наблюдаем тенденцию увеличения содержания поллютантов в мышцах и печени у более крупных особей по сравнению с особями меньшего размера (рис. 8.4). Эта же зависимость наблюдается и с увеличением возраста, так как млекопитающие накапливают токсиканты в течение всей жизни.

У самок тенденция к увеличению концентрации пестицидов наблюдается до наступления половой зрелости. После наступления репродуктивного возраста концентрации ХОП выходят на плато или даже уменьшаются [8]. Серые киты достигают половой зрелости в возрасте 5-10 лет, в среднем 8 лет [1]. Исследованные нами образцы органов и тканей были взяты у неполовозрелых самок, поэтому мы наблюдали только увеличение концентрации ХОП с возрастом.

Концентрация пестицидов в мышцах находилась в диапазоне 2973581 нг/г липидов, в печени - 769-13808 нг/г липидов (табл. 8.2 и рис. 8.5).

Статистически достоверных половых различий в содержании ГХЦГ и ДДТ в мышцах не обнаружено, однако имеется тенденция к увеличению концентрации ксенобиотиков в самцах (кроме ДДТ и ДДД, которые не 
обнаружены). В печени самцов, по сравнению с самками, достоверно выше только концентрация $\alpha$-ГХЦГ ( $\mathrm{p}=0,05)$, однако, как можно видеть, концентрация всех остальных ксенобиотиков увеличивается в самцах. Низкая статистическая достоверность полученных результатов, вероятно, связана с малым количеством выборок.
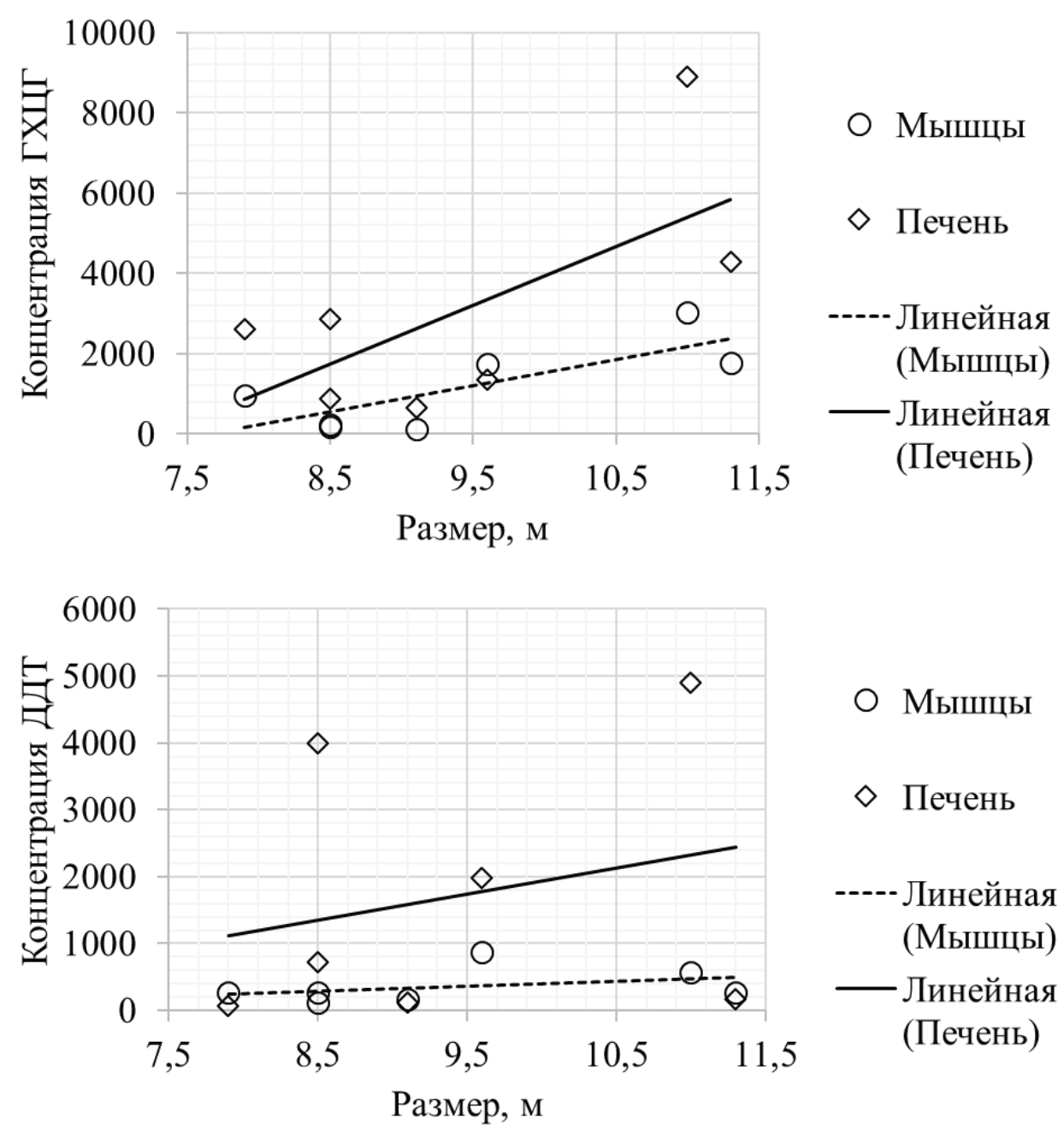

Puc. 8.4. Зависимость концентрации ГХЦГ и ДДТ в органах серого кита от размера тела

Общее содержание различных хлорорганических пестицидов в мышцах и печени серого кита показано в таблице 8.2.

Статистически достоверные различия между мышцами и печенью обнаружены только $\beta$-ГХЦГ ( $\mathrm{p}=0,002)$. Что касается других загрязняющих веществ, то ДДТ и его метаболиты имеют тенденцию к увеличению в печени, ГХЦГ - в мышцах. 
Таблица 8.2

Средние (числитель) и диапазоны (знаменатель) концентрации ХОП в органах серого кита, нг/г липидов

\begin{tabular}{|c|c|c|c|c|c|c|}
\hline Органы & $\alpha$-ГХЦГ & $\beta$-ГХЦГ & $\gamma$-ГХЦГ & ДДТ & ДДД & ДДЕ \\
\hline \multirow[t]{2}{*}{ Мышцы } & $728 \pm 733$ & $\underline{131 \pm 257}$ & $285 \pm 356$ & $\underline{44 \pm 117}$ & $<\Pi$ & $\underline{317 \pm 175}$ \\
\hline & $\overline{70-1974}$ & $\overline{\Pi О-676}$ & $\overline{14-1043}$ & $\overline{\Pi \mathrm{\Pi O}-310}$ & & $\overline{121-565}$ \\
\hline \multirow[t]{2}{*}{ Печень } & $\underline{1047 \pm 2257}$ & $1499 \pm 909$ & $535 \pm 881$ & $481 \pm 729$ & $34 \pm 91$ & $\underline{1192 \pm 1243}$ \\
\hline & $72-6160$ & $392-2754$ & ПО-2161 & ПО-1552 & ПО-240 & $71-3132$ \\
\hline
\end{tabular}

ПО - предел обнаружения.
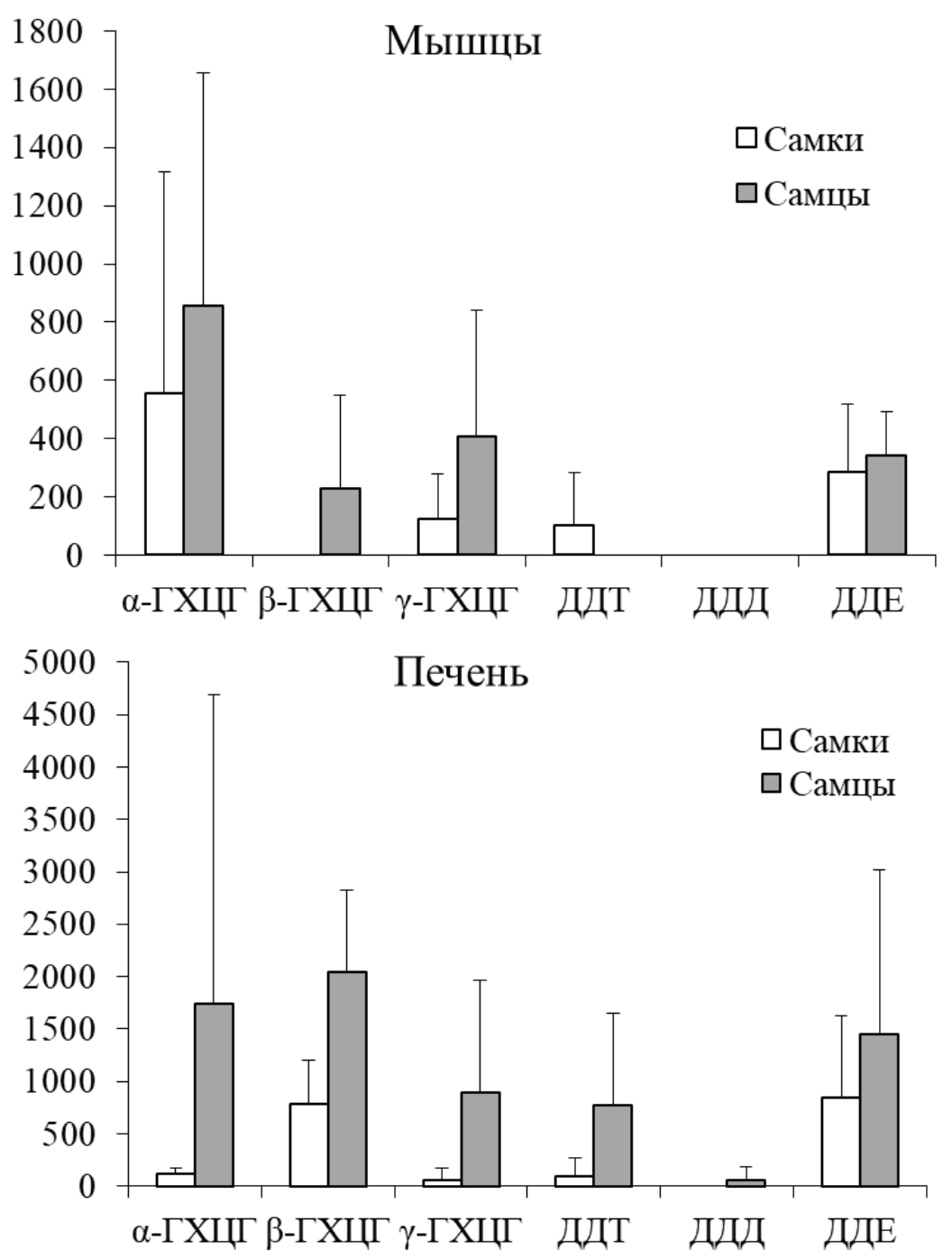

Puc. 8.5. Концентрации ХОП в мышцах и печени самок и самцов серого кита, нг/Г липидов

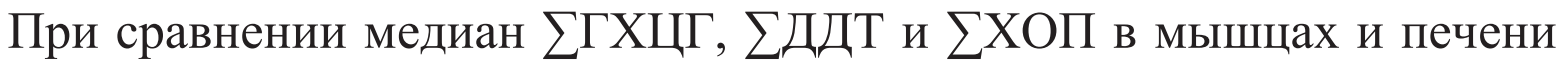
видно, что органы значительно различаются только по содержанию 


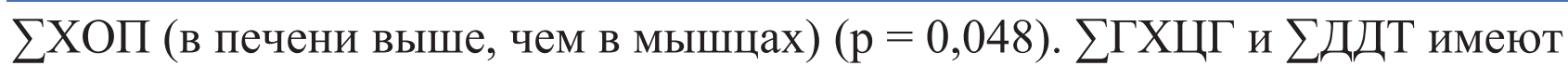
лишь тенденцию к увеличению в печени.

\subsection{2. Тихоокеанский моржс (Odobenus rosmarus divergens)}

Пестициды найдены во всех пробах моржа. Диапазон концентраций ХОП в органах животного находился в широких пределах. Концентрация пестицидов в печени была значительно выше, чем в мышцах. В мышцах самцов и самок суммарные концентрации ХОП сходны (рис. 8.6). Однако средняя концентрация в печени самок выше, чем у самцов. У последних наблюдается тенденция аккумуляции пестицидов с увеличением размера, как в мышцах, так и в печени.

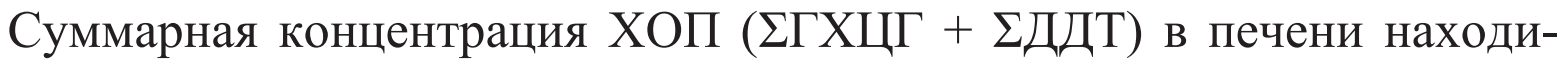
лась в диапазоне 4900-90300 нг/Г липидов. Эта величина существенно превышала диапазон в мышцах - 200-5700 нг/г липидов. В мышцах обнаружены все изомеры ГХЦГ и метаболит ДДТ, в печени - изомеры ГХЦГ, ДДТ и ДДЕ (табл. 8.3 и рис. 8.7$)$.
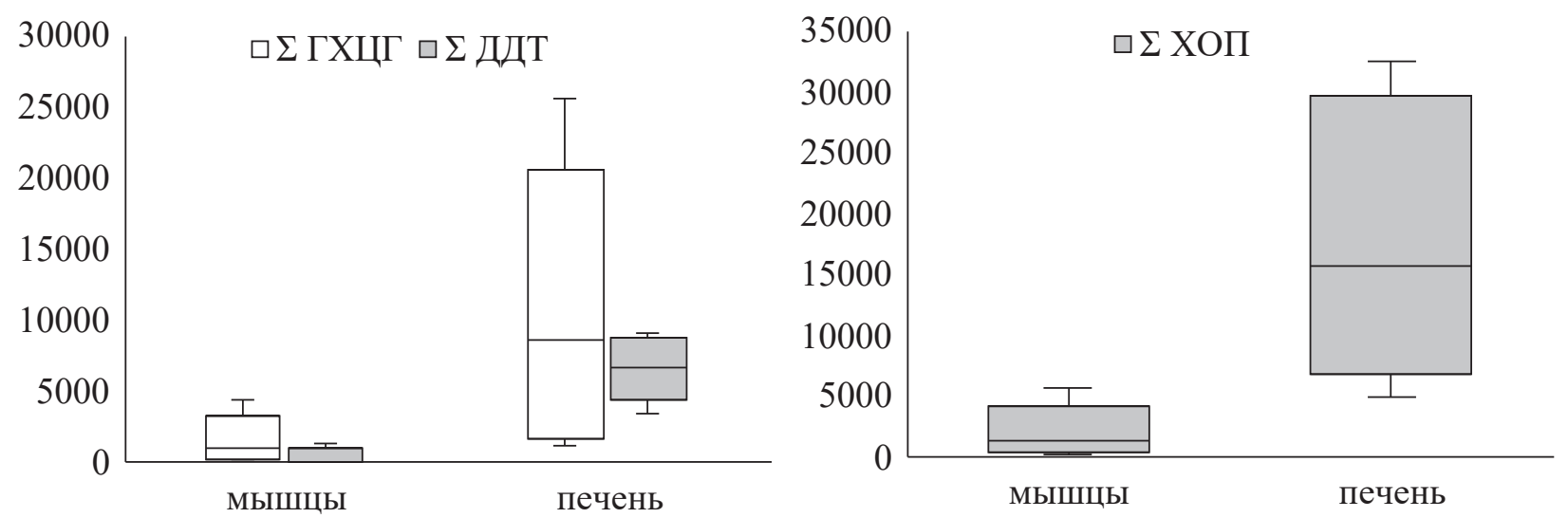

Puc. 8.6. Суммарное содержание ГХЦГ, ДДТ и ХОП

в мышцах и печени тихоокеанского моржа, нг/г липидов

Таблица 8.3

Средние концентрации (числитель) и диапазоны (знаменатель) ХОП

в органах тихоокеанского моржа, нг/Г липидов

\begin{tabular}{|c|c|c|c|c|c|}
\hline \multirow{3}{*}{ Мышцы } & 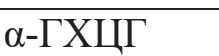 & $\beta$-ГХЦГ & $\gamma$-ГХЦГ & ДДТ & ДДЕ \\
\hline & $490 \pm 67$ & $\underline{405 \pm 402}$ & $728 \pm 9$ & $405 \pm 56$ & $<\Pi \mathrm{C}$ \\
\hline & ПО-1826 & ПО-916 & ПО-2482 & ПО-1287 & \\
\hline \multirow[t]{2}{*}{ Печень } & $\frac{8045 \pm 10647}{216}$ & $\frac{440 \pm 87}{\square 02536}$ & $2056 \pm 4085$ & $\frac{4474 \pm 3302}{\square 0161}$ & $\frac{9282 \pm 23546}{007238}$ \\
\hline & 216-25307 & ПО-2536 & ПО-12070 & 61 & 238 \\
\hline
\end{tabular}

ПО - предел обнаружения. 


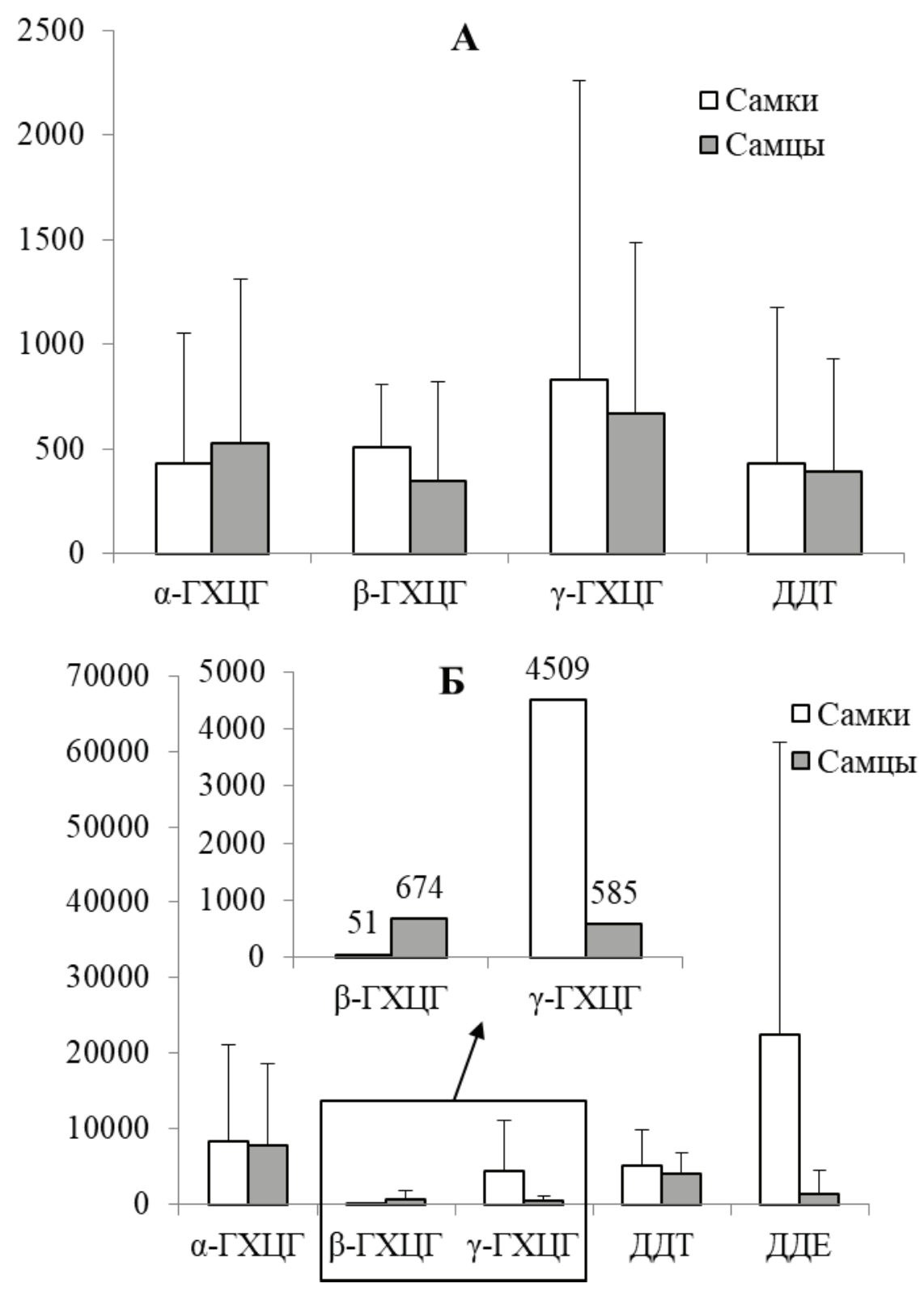

Puc. 8.7. Концентрации ХОП в мышцах (А) и печени (Б) самок и самцов серого кита, нг/Г липидов

Статистически достоверных различий между содержанием токсикантов в мышцах самцов и самок нет, однако концентрация всех поллютантов увеличивается в самках, кроме $\alpha$-ГХЦГ, который увеличивается в самцах (рис. 8.7A). В содержании токсикантов в печени, как и в мышцах, статистически достоверных различий нет, но концентрация всех обнаруженных пестицидов увеличивается в самках, кроме $\beta$-ГХЦГ, концентрация которого увеличивается в самцах (рис. 8.7Б).

Общее содержание различных хлорорганических пестицидов в мышцах и печени тихоокеанского моржа показано в таблице 8.3. Стати- 
стически достоверные результаты при сравнении органов получены только для двух веществ - $\alpha$-ГХЦГ $(\mathrm{p}=0,016)$ и ДДТ $(\mathrm{p}=0,021)$, их концентрация выше в печени. $\gamma$-ГХЦГ и ДДЕ имеют тенденцию к увеличению в печени, $\beta$-ГХЦГ - в мышцах.

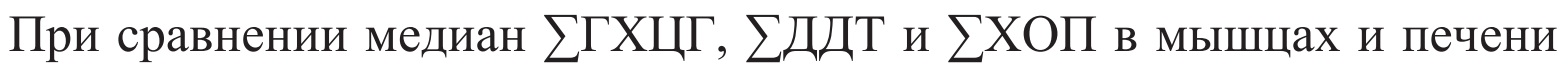
все результаты были статистически достоверны $(\mathrm{p}=0,001-0,036)$ и указывали на преобладание поллютантов в печени.

\subsection{3. Анализ ХОП в органах серого кита и тихоокеанского моржа}

В органах серого кита содержание липидов достигало 4\% в мышцах и 8\% в печени. В органах тихоокеанского моржа - до 6\% в мышцах и до 10\% в печени. Расчеты показали (табл. 8.4), что в среднем суммарное содержание ХОП в жире серого кита - 6290 нг/г, тихоокеанского моржа $26300 \mathrm{нг} / \Gamma$.

Таблица 8.4

\section{Среднее суммарное содержание ХОП в липидной фракции} серого кита и тихоокеанского моржа, нг/г липидов

\begin{tabular}{llll}
\hline Объект исследования & $\sum Г$ ХЦГ & $\sum$ ДДТ & $\sum$ ХОП \\
\hline Серый кит (Eschrichtius robustus) $(M \pm m, N=7)$ & $4220 \pm 1428$ & $2070 \pm 427$ & $6290 \pm 1855$ \\
$\begin{array}{l}\text { Тихоокеанский морж (Odobenus rosmarus } \\
\text { divergens) }(M \pm m, N=8)\end{array}$ & $14140 \pm 4125$ & $12160 \pm 2364$ & $26300 \pm 6489$ \\
\hline
\end{tabular}

Видовые особенности в аккумуляции липофильных ксенобиотиков у морских млекопитающих в немалой степени обусловлены общим содержанием жира в подкожной клетчатке и в отдельных органах. Большое значение также имеет и степень половозрелости особей. Исследованные нами виды имеют сходный ареал, и содержание жира в их органах отличается незначительно, составляя 8-10\%. Следовательно, существенные различия в содержании пестицидов могут быть связаны со стадией репродуктивного цикла и характером питания. Пищей серых китов служат в основном донные ракообразные и другие мелкие бентосные организмы, обитающие как на поверхности, так и в толще мягких грунтов (инфауна). Основу рациона моржа составляют донные беспозвоночные: двустворчатые моллюски, некоторые виды креветок, многощетинковых червей и приапулид, осьминоги и голотурии, а также некоторые виды рыб. Кроме того, 
иногда моржи поедают других тюленей: известны случаи нападения на кольчатую нерпу и детеныша гренландского тюленя [1].

Таким образом, возможными источниками поступления пестицидов в морскую среду в Беринговом море могут являться трансграничный атмосферный перенос и морские течения.

Концентрации ХОП в исследованных млекопитающих значительно ниже, чем таковые у полосатого дельфина (Stenella coeruleoalba) с cеверозападного побережья Японии, у косатки черной (Pseudorca crassidens) с побережья Гавайских островов, у косатки (Orcinus orca) с Восточных прибрежных зон от Калифорнии до Аляски, у беспёрой морской свиньи (Neophocaena phocaenoides) из прибрежной зоны Кореи, у Дюгоня (Dugong dugon) с северо-востока Австралии, у морского льва (Zalophus californianus), морского слона (Mirounga angustirostris) и тюленя обыкновенного (Phoca vitulina) из урбанизированных районов Калифорнии. Однако, это значение больше, чем содержание ХОП у морской свиньи (Phocaena phocaena relicta) и большого дельфина (Tursiops truncatus) из Черного моря и тюленя обыкновенного (Phoca vitulina) из удаленных от загрязнения районов Калифорнии (табл. 8.5).

Из данных таблицы 8.5 видно, что суммарное содержание ДДТ и его метаболитов в органах морских млекопитающих из других районов Мирового океана, как правило, выше, чем сумма изомеров ГХЦГ. Например, у полосатого дельфина из прибрежных вод Японии суммарное количество ДДТ достигает 130000 нг/г, тогда как ГХЦГ - только 520 нг/г. У серого кита и тихоокеанского моржа отмечена обратная закономерность, содержание ГХЦГ заметно преобладает над ДДТ. Количественное преобладание ГХЦГ над ДДТ отмечено также у морских организмов из залива Петра Великого Японского моря $[17,24]$. Эти факты, по-видимому, отражают большее использование линдана и технического ГХЦГ в сельском хозяйстве Дальневосточного региона России.

Таким образом, в органах китов чукотско-калифорнийской популяции и тихоокеанских моржей наблюдается накопление пестицидов, но общий уровень их содержания значительно ниже, чем у морских млекопитающих из других районов Мирового океана. 


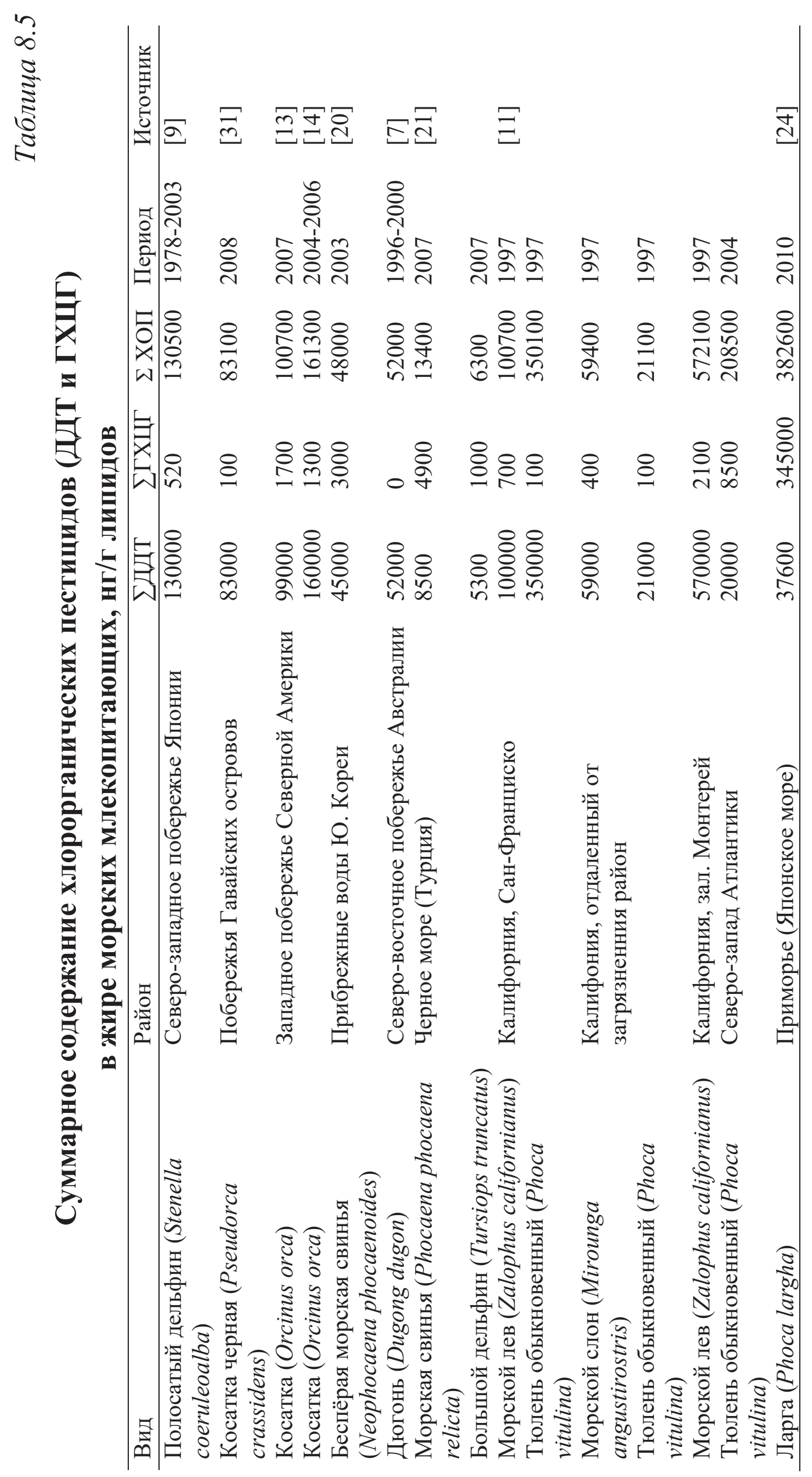




\section{3. Заключение}

Разный уровень аккумуляции пестицидов у отдельных видов птиц в первую очередь отражает пищевые предпочтения, состав рациона, миграции, содержание жира в отдельных органах. Кормовые объекты моржа аккумулируют больше пестицидов в теле, чем компоненты рациона серого кита, так как коэффициенты накопления поллютантов у моллюсков и рыб выше, чем у ракообразных. На основании этого можно заключить, что пищевой фактор является определяющим в различиях аккумуляции пестицидов у китов и моржей. Следовательно, морские птицы и млекопитающие являются моделями глобального загрязнения биосферы хлорорганическими поллютантами, которые подтверждают актуальность международной проблемы загрязнения водной и воздушной сред жизни.

\section{4. Список литературы}

1. Бурдин, А.М. Морские млекопитающие России: справочникопределитель / А.М. Бурдин, О.А. Филатова. - Киров: Кировская областная типография, 2009. - 206 с.

2. Медведев, Н.В. Экологическая токсикология природных популяций птиц и млекопитающих Севера / Н.В. Медведев, Э.В. Ивантер. - М.: Наука, 2007. - 229 с.

3. Ровинский, Ф.Я. Фоновый мониторинг загрязнения экосистем суши хлорорганическими соединениями / Ф.Я. Ровинский, Л.Д. Воронова, М.И. Афанасьев, А.В. Денисова, И.Г. Пушкарь. - Л.: Гидрометеоиздат, 1990. $-270 \mathrm{c}$.

4. Цыганков, В.Ю. Гексахлорциклогексан и ДДТ в морских организмах Охотского и Берингова морей / В.Ю. Цыганков, М.Д. Боярова, О.Н. Лукьянова, Н.К. Христофорова // Известия ТИНРО. - 2014. - Т. 176. P. 225-232.

5. Цыганков, В.Ю. Стойкие токсические вещества в мышцах и печени тихоокеанского моржа Odobenus rosmarus divergens Illiger, 1815 из Берингова моря / В.Ю. Цыганков, М.Д. Боярова, О.Н. Лукьянова // Биология моря. - 2014. - Т. 40. - № 2. - С. 158-161. 
6. Buckman, A.H. Organochlorine contaminants in seven species of Arctic seabirds from northern Baffin Bay / A.H. Buckman, R.J. Norstrom, K.A. Hobson [et al.] // Environmental Pollution. - 2004. - V. 128. - P. 327-338.

7. Haynes, D. Organichlorine and heavy metal concentrations in blubber and liver tissue collected from Queensland (Australia) Dugong (Dugong dugon) / D. Haynes, S. Carter, C. Gaus [et al.] // Marine Pollution Bulletin. - 2005. V. 51. - P. 361-369.

8. Hickie, B.E. Killer Whales (Orcinus orca) Face Protracted Health Risks Associated with Lifetime Exposure to PCBs / B.E. Hickie, P.S. Ross, R.W. Macdonald, J.K.B. Ford // Environmental Science \& Technology. - 2007. V. 41. - P. 6613-6619.

9. Isobe, T. Organohalogen contaminants in striped dolphin (Stenella coeruleoalba) from Japan: Present contamination status, body distribution and temporal trends (1978-2003) / T. Isobe, Y. Ochi, S. Tanabe [et al.] // Marine Pollution Bulletin. - 2009. - No. 58. - P. 396-401.

10. Jorundsdottir, H. Organochlorine Compounds and Their Metabolites in Seven Icelandic Seabird Species - a Comparative Study / H. Jorundsdottir, K. Lofstrand, J. Svavarsson [et al.] // Environmental Science \& Technology. - 2010. - V. 44. - P. 3252-3259.

11. Kajiwara, N. Organochlorine pesticides, polychlorinated biphenyls and butyltin compound in blubber and liver of stranded Californian sea lions, Elephant seals and Harbor seals from coastal California, USA / N. Kajiwara, K. Kannan, M. Muraoka [et al.] // Archives of Environmental Contamination and Toxicology. - 2001. - V. 41. - P. 90-91.

12. Knudsen, L.B. Halogenated organic contaminants and mercury in dead or dying seabirds on Bjornoya (Svalbard) / L.B. Knudsen, K. Sagerup, A. Polder [et al.] - Norwegian polar institute, 2007. - 45 p.

13. Krahn, M.M. Effects of age, sex and reproductive status on persistent organic pollutant concentrations in "Southern Resident" killer whales / M.M. Krahn, M.B. Hanson, R.W. Baird [et al.] // Marine Pollution Bulletin. 2009. - V. 58. - P. 1522-1529.

14. Krahn, M.M. Persistent organic pollutants and stable isotopes in biopsy samples (2004/2006) from Southern Resident killer whales / M.M. Krahn, M.B. Hanson, R.W. Baird [et al.] // Marine Pollution Bulletin. - 2007. - V. 54. P. 1903-1911. 
15. Kunisue, T. Accumulation features of persistent organochlorines in resident and migratory birds from Asia / T. Kunisue, N. Watanabe, A.N. Subramanian [et al.] // Environmental Pollution. - 2003. - V. 125. P. 157-172.

16. Leat, E.H.K. Effects of environmental exposure and diet on levels of persistent organic pollutants in eggs of a top predator in the North Atlantic in 1980-2008 / E.H.K. Leat, S. Bourgeon, K. Borgå [et al.] // Environmental Pollution. - 2011. - V. 159. - No. 5. - P. 1222-1228.

17. Lukyanova, O.N. Persistent organic pollutants in marine ecosystems in Russian Far East: Sources, transport, biological effects / O.N. Lukyanova. LAP Lambert Academic Publishing, 2013. - 108 p.

18. Lukyanova, O.N. Pesticide biotransport by Pacific salmon in the northwestern Pacific Ocean / O.N. Lukyanova, V.Y. Tsygankov, M.D. Boyarova, N.K. Khristoforova // Doklady Biological Sciences. - 2014. - V. 456. - P. 188-190.

19. Morales, L. Persistent Organic Pollutants in gull eggs of two species (Larus michahellis and Larus audouinii) from the Ebro delta Natural Park / L. Morales, M.G. Martrata, J. Olmos [et al.] // Chemosphere. - 2012. - V. 88. No. 11. - P. 1306-1316.

20. Park, B. Organohalogen contaminants in finless porpoises (Neophocaena phocaenoides) from Korean coastal waters: Contamination status, maternal transfer and ecotoxicological implications / B. Park, G. Park, Y. An, H. Choi [et al.] // Marine Pollution Bulletin. - 2010. - V. 60. - P. 768-774.

21. Popa, O.M. Organochlorine pesticides in the Black Sea dolphins / O.M. Popa, A. Trif, N. Marine, N. Ursu // Lucrari stiintifice medicina veterinara. Timisoara. - V. XLI. - 2008. - P. 768-773.

22. Tanabe, S. Bioindicators of POPs / S. Tanabe, A. Subramanian. Japan: Kyoto University Press and Trans Pacific Press, 2006. - 190 p.

23. Tanabe, S. Contamination by Persistent Toxic Substances in the Asia-Pacific Region / S. Tanabe // Persistent Organic Pollutants in Asia: Sources, Distributions, Transport and Fate. - A. Li, S. Tanabe, G. Jiang, J.P. Giesy and P.K.S. Lam (Editors). - Developments in Environmental Science. -2007. - V. 7. - P. 773-817.

24. Trukhin, A.M. Chlorinated pesticides in tissues and organs of spotted seals (Phoca largha Pallas, 1811) from the Sea of Japan / A.M. Trukhin, M.D. Boyarova // Contemporary Problems of Ecology. - 2013. - V. 6. P. 336-342. 
25. Tsygankov, V.Yu. Bioaccumulation of organochlorine pesticides (OCPs) in the northern fulmar (Fulmarus glacialis) from the Sea of Okhotsk / V.Yu. Tsygankov, M.D. Boyarova, O.N. Lukyanova // Marine Pollution Bulletin. $-2016 .-$ V. 110. - P. 82-85.

26. Tsygankov, V.Yu. Bioaccumulation of Persistent Organochlorine Pesticides (OCPs) by Gray Whale and Pacific Walrus from the Western Part of the Bering Sea / V.Yu. Tsygankov, M.D. Boyarova, O.N. Lukyanova // Marine Pollution Bulletin. - 2015. - V. 99. - P. 235-239.

27. Tsygankov, V.Yu. Bioindicators of organochlorine pesticides (OCPs) in the Sea of Okhotsk and the western Bering Sea / V.Yu. Tsygankov, M.D. Boyarova, O.N. Lukyanova, N.K. Khristoforova // Archives of Environmental Contamination and Toxicology. - 2017. - V. 73. - P. 176-184.

28. Tsygankov, V.Yu. Persistent toxic substances in the muscles and liver of the pacific walrus Odobenus rosmarus divergens Illiger, 1815 from the Bering Sea / V.Yu. Tsygankov, M.D. Boyarova, O.N. Lukyanova // Russian Journal of Marine Biology. - 2014. - V. 40. - P. 147-151.

29. Wania, F. Global fractionation and cold condensation of low volatility organochlorine compounds in polar regions / F. Wania, D. Mackay // Ambio. - 1993. - V. 22. - P. 10-18.

30. Wania, F. Tracking the distribution of persistent organic pollutants / F. Wania, D. Mackay // Environmental Science \& Technology. - 1996. - V. 30. No. 9. - P. 390-396.

31. Ylitalo, G.M. High levels persistent organic pollutants measured in blubber of island-associated false killer whales (Pseudorca crassidens) around the main Hawaiian Island / G.M. Ylitalo, R.W. Baird, G.K. Yanagida [et al.] // Marine Pollution Bulletin. - 2009. - No. 58. - P. 1932-1937. 